\title{
Sustainable Waste Management for Green Highway Initiatives
}

\author{
Nur Illiana Husin ${ }^{1, a}$, Asmalia Che Ahmad² ${ }^{2}$ Abdul Muhaimin Ab Wahid² and Syahrul Nizam Kamaruzzaman ${ }^{3}$ \\ ${ }^{1}$ Department of Built Environment, Faculty of Architecture, Planning and Surveying, Universiti Teknologi Mara (Shah Alam), Malaysia \\ ${ }^{2}$ Department of Quantity Surveyor, Faculty of Architecture, Planning and Surveying, Universiti Teknologi Mara (Shah Alam), Malaysia \\ ${ }^{3}$ Department of Building Surveying, Faculty of Built Environment, Universiti Malaya, Malaysia
}

\begin{abstract}
Green highway initiative is the transportation corridors based on sustainable concept of roadway. It incorporates both transportation functionality and ecological requirements. Green highway also provides more sustainable construction technique that maximizes the lifespan of highway. Waste management is one of the sustainable criterias in the elements of green highway. Construction of highway consumes enormous amounts of waste in term of materials and energy. These wastes need to be reduce to sustain the environment. This paper aims to identify the types of waste produced from highway construction. Additionally, this study also determine the waste minimization strategy and waste management practiced.. This study main focus are construction and demolition waste only. The methodology process begin with data collection by using questionnaire survey. 22 concession companies listed under Lembaga Lebuhraya Malaysia acted as a respondent. The questionnaires were distributed to all technical department staffs. The data received was analyzed using IBM SPSS. The results shows the most production of waste is wood, soil, tree root and concrete. The least production of waste is metal. For waste minimization, the best waste minimization is reuse for all type of waste except for tree root and stump. Whereas, the best waste management is providing strategic plan. The least practice for waste management is recording the quantity of waste.
\end{abstract}

\section{Introduction}

Development of green highway is revitalizing in the developing country [1]. The development of green highway includes design of highway in such a manner that improves the quality of nation's infrastructure [1]. With the demands in implementation of major infrastructure projects in Malaysia together with the commercial and housing development, a large amount of construction waste is being produced by the construction sector [2]. In study by Wokekoro (2007), construction sector generates large amount of waste and contributes to the environmental problem [3]. The construction waste become an issues that needs highly concern in many developing countries because it has an adverse effect on economy, environment and social aspects.

According to GEC (2012), solid waste is one of the three major environmental problems in Malaysia [4]. Over 23,000 tonnes of waste is produced each day in Malaysia. The amount of solid waste is expected to rise to 30,000 tonnes by the year of 2020 [4]. In Malaysia, there are almost 1800 rivers, but more than half of the rivers have been polluted and destroyed because of the improper solid waste management [4]. The management of solid waste is important to reduce or eliminates the adverse impacts on the environment and human health.

Papargyropoulou et al. (2011) reported 28 per of solid waste originated from industrial and construction waste in the central and southern regions of Malaysia [5]. It happens because of waste minimization, reuse and recycling practices are limited in the construction sector. Besides, the natural resources required as construction materials are available at relatively low cost [6]. In addition, Begum et al. (2009) stated there is no mandatory requirement for construction companies to practice sustainable resource and waste management [6]. Hence, this study is constructed to identify types of waste produced during construction activity. Additionally, this study also handled to determine the best waste minimization strategy and waste management practiced.

\section{Literature Review}

\subsection{Waste}

Waste can be defined as a material of solid or semi-solid character that the possessor no longer considers as a sufficient value to retain [3]. Formosa et al. (2002) clarified waste as a wastage sources likes materials, time (labor and equipment) and capital cost due to the direct or indirect activity, but not for the better or value of the final product according to customer satisfaction [7]. Waste is all waste arising from human and animal activities that are normally solid and being discard as useless or unwanted [8].

\footnotetext{
${ }^{\mathrm{a}}$ Corresponding author: nurillianahusin@gmail.com
} 
According to Pitchel (2005), waste is a material that possessed a negative economic value, which suggest that is cheaper to discard than to use [9]. Therefore, waste should be interpreted as any losses in material, time and monetary result by activities but do not add value or progress to the product, which can be eliminated without reducing customer value.

\subsection{Category and sources of waste}

Based on the literature research about the category and sources of waste, different author have their own category and sources of waste. Pitchel (2005) stated nine categories of waste such as municipal, hazardous, industrial, medical, universal, construction and demolition, radioactive, mining and agriculture waste [9]. Whereas, Bai \& Sutanto (2002) divided categories of waste into three which are domestic refuse, industrial and institution waste [10]. While for the sources of waste, have many sources of waste. Table 1 shows the sources of waste according to author.

Table 1. Sources of waste.

\begin{tabular}{|c|c|}
\hline Author & Sources of waste \\
\hline $\begin{array}{l}\text { Tchonobouglous et } \\
\text { al. (1993) [8] }\end{array}$ & $\begin{array}{ll}\text { a. } & \text { Commercial } \\
\text { b. } & \text { Institutional } \\
\text { c. } & \text { Construction and demolition } \\
\text { d. } & \text { Municipal service (excluding } \\
& \text { treatment plant sites) } \\
\text { e. } & \text { Treatment plant sites (municipal } \\
& \text { incinerators) } \\
\text { f. } & \text { Municipal solid waste } \\
\text { g. } & \text { Industrial } \\
\text { h. } & \text { Agriculture } \\
\end{array}$ \\
\hline Pitchel (2005) [9] & $\begin{array}{l}\text { a. Municipal - residential, commercial, } \\
\text { institutional, industrial, municipal } \\
\text { b. Hazardous - manufacture, } \\
\text { electroplating, metal treating, wood } \\
\text { preserving and petroleum refining } \\
\text { c. Industrial - manufacturing } \\
\text { d. Medical - hospital, physicians, } \\
\text { dentists, veterinarians, healthcare } \\
\text { facilities, clinics, laboratories, blood } \\
\text { banks and funeral homes } \\
\text { e. Universal - small and large business, } \\
\text { household } \\
\text { f. } \text { Construction and demolition - } \\
\text { construction, renovation and } \\
\text { demolition } \\
\text { g. Radioactive - specializes of industrial } \\
\text { waste, research and medical } \\
\text { h. Mining - physical removal of desired } \\
\text { resources } \\
\text { i. Agriculture - animal manures and } \\
\text { crop residues }\end{array}$ \\
\hline $\begin{array}{l}\text { Wokekoro (2007) } \\
\text { [3] }\end{array}$ & $\begin{array}{l}\text { a. Municipal - street sweeping, sewage, } \\
\text { waste form schools, market and other } \\
\text { institution } \\
\text { b. Domestic - garbage, rubbish and } \\
\text { large waste from homes } \\
\text { c. Commercial - stores and offices } \\
\text { d. Industrial - manufacturing plants } \\
\text { e. Mining - coal mining, strip mining }\end{array}$ \\
\hline
\end{tabular}

\begin{tabular}{|c|c|}
\hline & etc \\
\hline $\begin{array}{l}\text { Bai \& Sutanto } \\
\text { (2002) [10] }\end{array}$ & 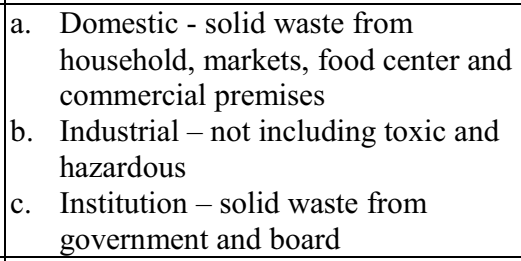 \\
\hline ONSW (2012) [11] & $\begin{array}{l}\text { a. Household } \\
\text { b. Commercial } \\
\text { c. Construction and demolition } \\
\text { d. Industrial } \\
\text { e. Institution } \\
\text { f. Public imported } \\
\end{array}$ \\
\hline $\begin{array}{l}\text { Environment } \\
\text { Strategies (2000) } \\
{[12]}\end{array}$ & $\begin{array}{l}\text { a. Residential } \\
\text { b. Industrial } \\
\text { c. Commercial } \\
\text { d. Instituted } \\
\text { e. Construction and demolition } \\
\text { f. Municipal } \\
\text { g. Manufacturing } \\
\text { h. Agriculture }\end{array}$ \\
\hline
\end{tabular}

\subsection{Waste management}

Based on Basri \& Ahmad Basri (2008), waste management is an integral part of urban and environmental management of each city [13]. Waste management is a major challenge for Malaysia to address in the light of vision 2020 which lays out of direction for Malaysia to become a fully developed nation by 2020 [14]. Waste management are designed to prevent or reduce the discharge of pollutants to stormwater from solid or construction waste by providing designated waste collection areas and containers, arranging for regular disposal, and training employees and subcontractors [15].

Tchobanoglous et al.(1993) described waste management as the discipline associated with the control of generation, storage, collection, transfer and transport, processing, and disposal of solid wastes in a manner that is correlate with the best principles of public health, economics, engineering, conservation, aesthetics, and other environmental considerations, and that is also responsive to public attitude [8]. According to Pitchel (2005), waste management is concerned with the generation, on site storage, collection, transfer, transportation, processing and recovery, and ultimate disposal of solid waste [9].

In other word, waste management is a management process to ensure waste generated will be treated in the right way. It aims to reduce the production of waste and to reduce the amount of waste going to landfill. It is also to reduce the environmental problem that becomes a major problem nowadays.

\subsection{Waste minimization}

Environmental Protection Agency (EPA) of United States (2000) defined waste minimization as any method that reduces the volume or toxicity of a waste that requires disposal [12]. It is including any method that reduces the amount of waste. Government regulations, as well as internal cost effectiveness, required the disposal of all 
waste and in particularly hazardous waste be minimized.

Waste minimization explained by Poon, Ann, \& Jaillon (2004) as any technique, process or activity which avoids, eliminates or reduces waste from its source or allows reuse or recycling of the waste [16]. Figure 1 shows the waste management hierarchy determined by Poon, Ann \& Jaillon (2004). The waste minimization are divided into prevention measures and waste management measures. The prevention measures are consist of prevention, reduction at source and re-use of product. Meanwhile, the waste management measure category consists of quality improvements, recycling, energy recovery and pre-treatment.

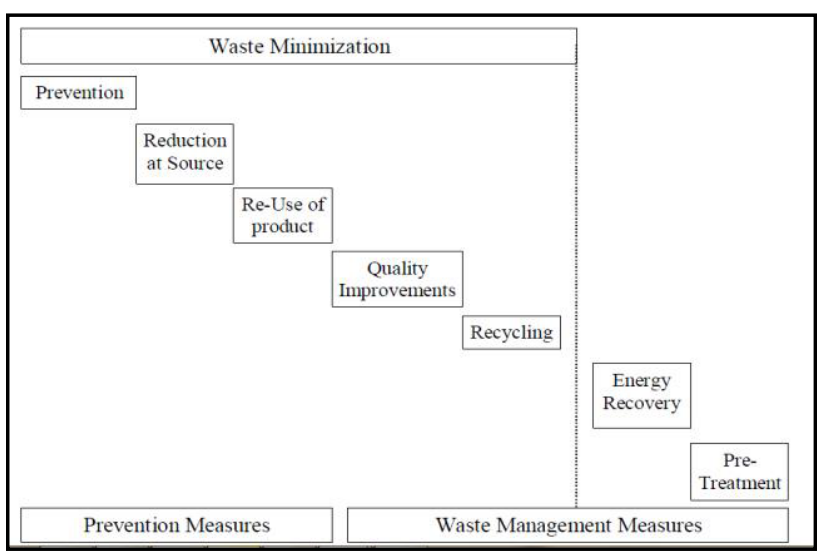

Figure 1. Waste minimization hierarchy [16].

Faniran \& Caban (1998) wrote there are three main waste minimization strategies which are avoiding waste, reusing materials and recycling waste. Avoiding waste refer to any practice or process that avoids, eliminates or minimizes waste at the source [17]. In the meantime, reusing and recycling waste supports in reducing the volume of waste material to be disposed and discharged into environment. Figure 2 shows proposed waste management hierarchy that consists of avoid, reuse, recycle and disposal by Faniran \& Caban (1998).

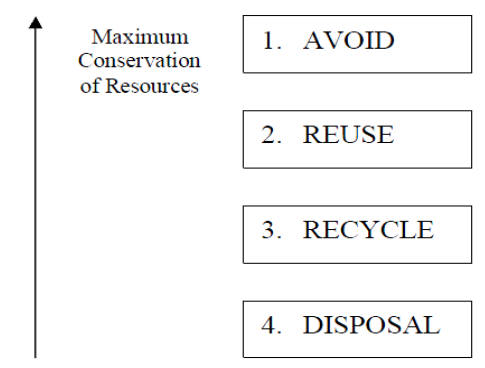

Figure 2. Waste minimization hierarchy [17].

\subsection{Waste management plan}

Macozama (2002) expounded waste management plan as a proposal that consists of prevention, isolation, repair, reuse, recycle and also disposal of waste [18]. The main objective of waste management plan is to reduce, reuse and recycle of waste [19]. Moreover, Macozama (2002) has identified the good management plan which are goals, waste audit, waste handling requirement, waste disposal, transportation and economic evaluation [18]. On top of that, Lim \& Ling (2002) has categorized the element of waste management plan to 4 categories which are including the prevention of waste, reduction, recycle and administration [20]. A good waste management plan will assist to reduce amount of waste going to landfill and minimize the cost to manage the waste.

\section{Methodology}

The methodology process begins with data collection by using questionnaire survey. This study is using purposive sampling method. Concession Company has been choosing as a respondent. There are 22 concession companies listed under Lembaga Lebuhraya Malaysia. The questionnaire had been distributed to all technical department staffs. Only 50 sets of questionnaire are returned. The data collected has been analyzed using IBM SPSS.

\subsection{Development of questionnaire}

The questionnaire has four parts which are demographic, types of waste, waste minimization strategy and waste management. The development of questionnaire built according to close ended with Likert scale 1 to 5 . Scale 1 refers to strongly disagree and scale 5 refer to strongly agree. The question was designed using interval scale.

The categories and sources of waste used in the questionnaire were followed from Pitchel (2005) as he had clearly stated the variables in his research study [9]. The categories are divided into municipal, hazardous, industrial, medical, universal, construction and demolition, radioactive, mining and agriculture. For this study, the category used is correlated to construction and demolition. Then, the sources of waste come from the highway construction itself.

The hierarchy of the waste management has been chosen from Poon et. al (2004) [16]. It is because the study did not only focus on the basic waste minimization only (prevent, reuse, recycle and disposal) but it also consists of prevention, reduction at source, reuse of product, quality improvement, recycling, energy recovery and pretreatment. This hierarchy helps to guide people to choose the best way of managing the waste properly.

Table 2 shows the variable for waste management plan that will be discussed in waste management plan in section 4.3 .

Table 2. Variable for waste management plan.

\begin{tabular}{|c|c|}
\hline Indicator & Waste management plan \\
\hline A & Provide strategic management plan \\
\hline B & Policy regarding waste management \\
\hline C & Employees with responsibility to manage waste \\
\hline D & Identifying the type of waste \\
\hline E & Organize the waste \\
\hline F & Record the quantity of waste \\
\hline G & Management of waste \\
\hline H & Training employees \\
\hline I & Measure \& Audit \\
\hline
\end{tabular}




\begin{tabular}{|l|l|}
\hline $\mathrm{J}$ & Review plan \\
\hline
\end{tabular}

\section{Result and findings}

The result obtained from the questionnaire shows 20 out of 50 respondents have working experience in this field more than 10 years. The other 13 respondents stated with 5 to 10 years working experience and 12 respondents have less than 5 years working experience. From this conclusion, it shows almost half of the respondents have more than 10 years working experience in construction industry. Although only 50 sets of questionnaire are returned, data given can be accepted because of the respondent are knowledgeable and experienced in the related industry. Further, in subheading 4.1 discussed the outcomes of type of waste produced. Then, subheading 4.2 discussed of waste minimization strategy and 4.3 is waste management practiced.

\subsection{Types of waste}

Table 3 below shows the average index for waste produced during the construction and demolition of highway. The formula of average index is taken from study by Al-Hammad \& Assaf (1996) [21]. Below (1) is the formula for calculation of average index.

$$
\text { Average index }=\frac{\sum a 1 x 1}{\sum x 1}
$$

Indicator :-

$$
\begin{array}{ll}
\mathrm{a} 1= & \text { Likert scale (i.e 1 'no production' }- \\
& 5 \text { 'most production') } \\
\mathrm{x} 1= & \text { Number of respondent }
\end{array}
$$

The waste involves are tree root or stump, soil, concrete, asphalt, wood, metal, rock, aggregate, sand, crusher run, bituminous, and premix. The top ranking of production of waste are wood (3.2000), followed by soil (3.160) and tree root or stump with same average index with concrete (3.000) and crusher run with aggregate (2.780). The rock comes with aggregate 2.960 and premix (2.680). It is followed by asphalt and bituminous (2.640) and the lowest rank of all is metal with 2.6000 aggregate.

The highest rank of waste is wood 3.200 average. Wood is always used as a temporary support especially for concreting work. The nature of wood that easy to rot also become one of the reason why wood reflects as the highest production of waste. It is supported by study of Lachimpadi et al. (2012) also found wood is the largest quantity of construction waste [22].

The second ranking is soil 3.160 average. Different site will produce different quantity of soil. It depends on condition of sites whether it needs to be cut or filled to get a flat ground before construction could begin. Lachimpadi et al. (2012) conclude the generation of soil waste greatly depended on the design and the landscape of the site [22]. If the site located at hilly area, it will involve a lot of cutting compared to fills. Thus, the surplus of soil will be classified as soil waste. It is also supported in the study by Begum et al. (2006) that soil and sand are the second highest waste for their study [6].

On the other hand, metal contemplated as the lowest ranking with 2.600 average. Metal become the lowest production because of the limited usage in the construction of highway. It is because the metal is always custom made from the factory. It will be delivered to site according to the quantity and size order. In article by

\begin{tabular}{|c|c|c|c|c|c|c|c|c|c|}
\hline Bill & Types of waste produce & $\begin{array}{c}1 \\
\text { a1 }\end{array}$ & $\begin{array}{c}2 \\
\text { a1 }\end{array}$ & $\begin{array}{c}3 \\
\text { a1 }\end{array}$ & $\begin{array}{c}4 \\
\text { a1 }\end{array}$ & $\begin{array}{c}5 \\
\text { a1 }\end{array}$ & $\begin{array}{c}\begin{array}{c}\text { Total } \\
\text { frequency }\end{array} \\
\sum \mathrm{a} 1 \mathrm{x} 1\end{array}$ & $\begin{array}{l}\begin{array}{c}\text { Average } \\
\text { Index }\end{array} \\
\sum \mathrm{a} 1 \mathrm{x} 1 \\
\sum \mathrm{x} 1\end{array}$ & Ranking \\
\hline & & $\mathrm{x} 1$ & $\mathrm{x} 1$ & $\mathrm{x} 1$ & $\mathrm{x} 1$ & $\mathrm{x} 1$ & & & \\
\hline 1 & Tree Root / Stump & 3 & 14 & 20 & 6 & 7 & 150 & 3.000 & 3 \\
\hline 2 & Soil & 0 & 14 & 21 & 8 & 7 & 158 & 3.160 & 2 \\
\hline 3 & Concrete & 3 & 14 & 20 & 6 & 7 & 150 & 3.000 & 3 \\
\hline 4 & Asphalt & 3 & 20 & 19 & 8 & 0 & 132 & 2.640 & 10 \\
\hline 5 & Wood & 0 & 9 & 22 & 19 & 0 & 160 & 3.200 & 1 \\
\hline 6 & Metals & 3 & 19 & 23 & 5 & 0 & 130 & 2.600 & 12 \\
\hline 7 & Rock & 0 & 14 & 24 & 12 & 0 & 148 & 2.960 & 6 \\
\hline 8 & Aggregate & 0 & 19 & 23 & 8 & 0 & 148 & 2.780 & 7 \\
\hline 9 & Sand & 0 & 19 & 23 & 8 & 0 & 148 & 2.780 & 7 \\
\hline 10 & Crusher Run & 0 & 14 & 23 & 13 & 0 & 150 & 2.980 & 5 \\
\hline 11 & Bituminous & 3 & 20 & 19 & 8 & 0 & 132 & 2.640 & 10 \\
\hline 12 & Premix & 3 & 19 & 19 & 9 & 0 & 134 & 2.680 & 9 \\
\hline
\end{tabular}
Technologiya Metallov (2008) found, in Russia, the production of metal waste is also low [23].

Table 3. Average Index for types of waste produce.

\subsection{Waste minimization strategy}

Waste minimization strategy is the best way to minimize waste. This strategy of waste minimization consist of prevention, reduction at source, reuse of product, quality improvement, recycle, energy recovery, pre-treatment, and disposal. 
Analysis of data received was converted to the percentage value. Table 4 shows the percentage value for waste minimization strategy. Tree root or and stump shows recycle as the highest percentage for waste minimization. In this practice where the tree root and stump are recycled to produce garden decoration.

According to Suez Environment (2015), the tree root and stump are impossible to reuse [24]. Hence, they are suitable to be recycled as bench, table or any other decoration for garden decoration.

However, for all types of waste, the highest percentage of waste minimization is reuse of waste. These wastes are soil, concrete, asphalt, wood, metals, rock, aggregate, sand, crusher run, bituminous and premix. These wastes can be reused for other projects and other function. While these wastes come from raw material and were not easily damage. It also can be reused for sometimes.

Table 4. Percentage of waste minimization strategy.

\begin{tabular}{|c|c|c|c|c|c|c|c|c|c|c|c|c|c|}
\hline \multirow[t]{2}{*}{ No } & \multirow[t]{2}{*}{ Waste Minimization } & 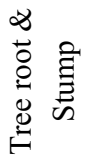 & $\overline{\bar{\delta}}$ & 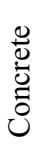 & $\begin{array}{l}\frac{\pi}{\pi} \\
\frac{\pi}{2} \\
\frac{2}{2}\end{array}$ & $\begin{array}{l}7 \\
8 \\
3\end{array}$ & 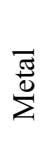 & $\begin{array}{l}\frac{y}{0} \\
0 \\
\simeq\end{array}$ & 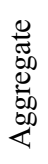 & 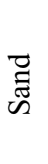 & 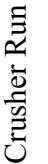 & 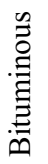 & 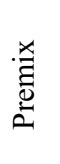 \\
\hline & & $\%$ & $\%$ & $\%$ & $\%$ & $\%$ & $\%$ & $\%$ & $\%$ & $\%$ & $\%$ & $\%$ & $\%$ \\
\hline 1. & Prevention & 5 & 5 & 0 & 0 & 4 & 0 & 0 & 0 & 0 & 0 & 0 & 0 \\
\hline 2. & Reduction at source & 0 & 14 & 3 & 15 & 3 & 4 & 3 & 4 & 4 & 4 & 15 & 15 \\
\hline 3. & Reuse of product & 13 & 68 & 69 & 75 & 56 & 70 & 74 & 81 & 87 & 75 & 66 & 60 \\
\hline 4. & Quality Improvement & 8 & 0 & 0 & 4 & 3 & 11 & 0 & 0 & 0 & 11 & 0 & 0 \\
\hline 5. & Recycle & 30 & 0 & 0 & 0 & 13 & 16 & 23 & 12 & 6 & 6 & 6 & 6 \\
\hline 6. & Energy Recovery & 0 & 0 & 0 & 0 & 0 & 0 & 0 & 0 & 0 & 0 & 0 & 0 \\
\hline 7. & Pre-treatment & 25 & 5 & 24 & 6 & 18 & 0 & 0 & 0 & 0 & 0 & 9 & 15 \\
\hline 8. & Disposal & 20 & 8 & 3 & 0 & 3 & 0 & 0 & 4 & 4 & 4 & 4 & 4 \\
\hline
\end{tabular}

\subsection{Waste management plan}

In waste management plan analysis preliminary test shows that the Cronbach's Alpha is 0.931 for 10 variables. There is high internal consistency for the data set which the Cronbach's Alpha is more than 0.7 [25]. This shows all the 10 variables are reliable to be analyzed for this research. The data for waste management plan was analyzed using Relative Importance Index (RII). RII to determine the relative importance of the waste management plan. The formula of RII as stated below (2) from Kometa et al. (1994) [26]. The higher the relative importance index value close to 1 means that the higher the position of the statement.

$$
\mathrm{RII}=\frac{\sum \mathrm{w}}{\mathrm{AN}}
$$

Indicator:-

$\mathrm{W}=$ Weights are given to each factor by the respondents and will ranges from 1 to 5 where ' 1 ' is strongly disagree and ' 5 ' is strongly agree

$\mathrm{A}=$ Highest weight (i.e. 5 in this case)

$\mathrm{N}=\mathrm{A}$ total number of respondents. The higher the index value close to 1 means that the higher the position of the statement

In table 5 shows from 10 variable of waste management plan. The highest RII is to provide strategic management plan (0.908). The second rank is organizing the waste with RII as 0.896 . The third rank is a policy regarding waste management $(0.888)$, followed by employees with responsibility to manage waste $(0.872)$ and management of waste $(0.864)$. These five variables are more than 0.850 and close to 1.000 which will be discussed as the main item in waste management plan.

From the analysis shows there is awareness among people to manage waste. It shows from the highest ranking which provides strategic management plan. These means many of the construction already have the strategic management plan to manage waste at construction site. In the study by Mahayuddin (2011) found all the construction sites have done a plan to manage and minimize the waste [27]. Besides that, organize waste also often practiced.

By referring to the indicator in table 2, table 6 shows the inter-item correlation matrix for variable in waste management plan. The value of correlation needs more than 0.50 [25]. In indicator A, there are three indicators that have not been practiced such as in indicator C, D and $\mathrm{F}$. The indicator $\mathrm{B}$ does not practice indicator $\mathrm{F}$ only. For indicator $\mathrm{C}$, indicator $\mathrm{A}$ and $\mathrm{F}$ get lower value than 0.50 . There are 3 indicators $(\mathrm{A}, \mathrm{B}, \mathrm{F})$ which are lower than 0.50 value for indicator $\mathrm{D}$. As for indicator $\mathrm{E}$, it is one indicator that does not have the correlation which is indicator F. From this analysis shows all the indicators does not have any correlation with the indicator $F$ which records the quantity of waste. It similar with the RII in table 5 where record quantity of waste having the lower RII (0.732).

The record of the quantity of waste is scarcely done. Study by Mahayuddin (2011) also found that from 10 sites, there are only 2 sites are implementing the 
recording of production of waste [27]. Hence, the recording waste of the production needs to be applied more in order to know the actual amount of waste produced. The data of waste produced can be a guideline to overcome or reduce the amount of waste for other project.

Table 5. Relative Importance Index for Waste Management Plan.

\begin{tabular}{|l|l|c|c|c|}
\hline Bill & \multicolumn{1}{|c|}{ Waste Management Plan } & $\begin{array}{c}\text { Total } \\
\text { weight of } \\
\text { statement } \\
\sum \mathrm{w}\end{array}$ & $\begin{array}{c}\text { Relative } \\
\text { Importance } \\
\text { Index } \\
\text { (RII) }\end{array}$ & Ranking \\
\hline & & & & \\
1. & Provide strategic management plan & 227 & 0.908 & 1 \\
2. & Organize the waste & 224 & 0.896 & 2 \\
3. & Policy regarding waste management & 222 & 0.888 & 3 \\
4. & Employees with responsibility to manage waste & 218 & 0.872 & 4 \\
5. & Management of waste & 216 & 0.864 & 5 \\
6. & Identifying the type of waste & 209 & 0.836 & 8 \\
7. & Measure \& audit & 211 & 0.844 & 7 \\
8. & Review Plan & 202 & 0.856 & 6 \\
9. & Training employees & 183 & 0.808 & 9 \\
10. & Record the quantity of waste & 0.732 & 10 \\
\hline
\end{tabular}

Table 6. Inter-item Correlation Matrix.

\begin{tabular}{|l|c|l|c|l|c|}
\hline Indicator & $\begin{array}{c}\text { Inter-Item Correlation } \\
\text { Matrix }\end{array}$ & Indicator & $\begin{array}{c}\text { Inter-Item Correlation } \\
\text { Matrix }\end{array}$ & Indicator & $\begin{array}{c}\text { Inter-Item Correlation } \\
\text { Matrix }\end{array}$ \\
\hline $\mathrm{A}-\mathrm{B}$ & 0.827 & $\mathrm{~B}-\mathrm{I}$ & 0.775 & $\mathrm{E}-\mathrm{F}$ & 0.122 \\
$\mathrm{~A}-\mathrm{C}$ & 0.424 & $\mathrm{~B}-\mathrm{J}$ & 0.564 & $\mathrm{E}-\mathrm{G}$ & 0.859 \\
$\mathrm{~A}-\mathrm{D}$ & 0.391 & $\mathrm{C}-\mathrm{D}$ & 0.743 & $\mathrm{E}-\mathrm{H}$ & 0.716 \\
$\mathrm{~A}-\mathrm{E}$ & 0.659 & $\mathrm{C}-\mathrm{E}$ & 0.795 & $\mathrm{E}-\mathrm{I}$ & 0.789 \\
$\mathrm{~A}-\mathrm{F}$ & 0.081 & $\mathrm{C}-\mathrm{F}$ & 0.251 & $\mathrm{E}-\mathrm{J}$ & 0.763 \\
$\mathrm{~A}-\mathrm{G}$ & 0.712 & $\mathrm{C}-\mathrm{G}$ & 0.856 & $\mathrm{~F}-\mathrm{G}$ & 0.338 \\
$\mathrm{~A}-\mathrm{H}$ & 0.650 & $\mathrm{C}-\mathrm{H}$ & 0.659 & $\mathrm{~F}-\mathrm{H}$ & 0.154 \\
$\mathrm{~A}-\mathrm{I}$ & 0.764 & $\mathrm{C}-\mathrm{I}$ & 0.772 & $\mathrm{~F}-\mathrm{I}$ & 0.369 \\
$\mathrm{~A}-\mathrm{J}$ & 0.493 & $\mathrm{C}-\mathrm{J}$ & 0.755 & $\mathrm{~F}-\mathrm{J}$ & 0.254 \\
$\mathrm{~B}-\mathrm{C}$ & 0.513 & $\mathrm{D}-\mathrm{E}$ & 0.766 & $\mathrm{G}-\mathrm{H}$ & 0.750 \\
$\mathrm{~B}-\mathrm{D}$ & 0.504 & $\mathrm{D}-\mathrm{F}$ & 0.438 & $\mathrm{G}-\mathrm{I}$ & 0.898 \\
$\mathrm{~B}-\mathrm{E}$ & 0.723 & $\mathrm{D}-\mathrm{G}$ & 0.623 & $\mathrm{G}-\mathrm{J}$ & 0.676 \\
$\mathrm{~B}-\mathrm{F}$ & 0.163 & $\mathrm{D}-\mathrm{H}$ & 0.439 & $\mathrm{H}-\mathrm{I}$ & 0.704 \\
$\mathrm{~B}-\mathrm{G}$ & 0.743 & $\mathrm{D}-\mathrm{I}$ & $\mathrm{D}-\mathrm{J}$ & $\mathrm{H}-\mathrm{J}$ & 0.622 \\
$\mathrm{~B}-\mathrm{H}$ & 0.592 & & 0.602 & $\mathrm{I}-\mathrm{J}$ & 0.860 \\
\hline
\end{tabular}

\section{Conclusion}

This academic research of waste management correlated to the implementation of green highway. In this study, it determined all possible types of waste produced by construction of highway. As for the production of waste, the highest ranking of all is wood while the lowest is metal. In addition, this research also discovered about the waste minimization strategy as well as the best way to manage the waste. Reuse method is concluded as the best practiced to minimize all type of waste except tree root and stump. These two items are using recycling method to reduce the waste. In terms of waste management strategy, it is a crucial activity for all construction sites to manage their waste properly. The management plan needed to follow and review accordingly in order to provide the best management practice. This plan must be included the actual record of the quantity of the waste for accurate wastage calculation.

In a nutshell, this study only focus on one out of five elements for green highway initiatives. Further research on material and technology, energy efficiency, stormwater management as well as safety and social factors. This research would contribute a big handful of guide for Lembaga Lebuhraya Malaysia as well as other countries with tropical climate.

\section{Acknowledgement}

The Authors wish to thank the Universiti Teknologi Mara and a remark of indebtedness to the Fundamental Research Grant Scheme (FRGS) by the Ministry of Education, Malaysia for its grant award. 


\section{References}

1. Bryce, J. M. (2008). Developing Sustainable Transportation Infrastructure. Retrieved from www.wiseintern.org/journal/2008/JamesBryceFina 1

2. Begum, R.A., Siwar, C., Pereira, J.J. \& Jaafar, A.H. (2007). A benefit-cost analysis on the economic feasibility of construction waste minimization: The case of Malaysia. Resources, Conservation and Recycling, 48(1), 86-98.

3. Wokekoro, E. (2007, 28-30 August). Solid waste management in the construction industry (a case study of Port Harcourt). Paper presented at the International Conference "Waste Management, Environment Geotechnology and Global Sustainable Development, Ljubljana, Slovenia.

4. Global Environment Centre (GEC). (2012). Solid Waste in Malaysia. Retrieved 14/07/2015, from www.gecnet.info/index.cfm?\&menuid $=83$

5. Papargyropoulou, E., Preece, C., Padfield, R. \& Abdullah, A.A. (2011). Sustainable Construction Waste Management in Malaysia: A Contractor's Perspective. Management and Innovation for a Sustainable Built Environment.

6. Begum, R.A., Siwar, C., Pereira, J.J. \& Jaafar, A.H. (2009). Attitude and behavioral factors in waste management in the construction industry of Malaysia. Resource, Conservation and Recycling., 53, 321-328.

7. Formoso, C. T., Soibelman, L., Cesare, C. D., \& Isatto, E. L. (2002). Material waste in building industry: Main causes and prevention. Journal of contruction engineering management, 128, 316325 .

8. Tchobanoglous, G., Theisin, H. \& Vigil, S.A. (1993). Integrated Solid Waste Management: Engineering Principles and Management Issues. Singapore: McGRAW-HILL.

9. Pitchel, J. (2005). Waste Management Practices: municipal, hazardous, and industrial. United State: Taylor \& Francis Group.

10. Bai R. \& Sutanto M. (2002). The practice and challenges of solid waste management in Singapore. Journal of waste management, 22, 557567.

11. Official national solid waste management (ONSW). (2012). Retrieved 05/08/2015, from http://www.kpkt.gov.my/jpspn_en/main.php

12. Environment Strategies for Cities. (2000). Sources and Types of Solid Waste. Retrieved 11/06/2015, from web.mit.edu/urbanupgrading/urbanEnvion ment/sectors/solidw-waste-sorces.html

13. Basri, H., \& Ahmad Basri N.E. (2008). UrusSisa: An Intelligent System for Integrated Solid Waste
Managament. Journal of Sustainable Development, 1(2), 39-46.

14. United Nations Development Programme (UNDP) (2008). Malaysia developing a solid waste management model for Penang. Retrieved 28/12/2015, from http://www.undp.org.my/Uploa ds/SWM-2008_final.pdf

15. California Stormwater Quality Association (CASQA). (2014). Retrieved 15/06/2015, from http://www.cabmphandbooks.com/Documents/Co nstruction/WM-05.pdf

16. Poon, C.S., Ann, T.W.Y. \& Jaillon, L. (2004). Reducing Building waste at construction sites in Hong Kong. Construction Management \& Economics, 22(5), 461-470.

17. Faniran, O. O., \& Caban, G. (1998). Minimizing waste on Construction project sites. Engineering, Construction and Architectural management, 5 Iss: 2, 182-188.

18. Macozoma, D.S. (2002). International report construction site waste management and minimisation. International Council for Research and Innovation in Building and Construction (CIB). Report No. BOU/C361.

19. Bruce, M. \& Smitchers, M. (1998). Implementing a waste management plan during the construction phase of project: a case study. Construction Management \& Economics, 16(1), 71-78.

20. Lim, M.C.H. \& Ling, F.Y.Y. (2002). Implementation solid waste management plan for construction projects in Singapore. Architectural Science Review 45: Taylor \& Francis Group.

21. Al-Hammad, A. M. \& Assaf, S. (1996) Assessment of work performance of maintenance contractors in Saudi Arabia. Journal of management in engineering, 12(1996), 44 - 49.

22. Lachimpadi, S. K., Pereira, J. J., Taha, M. R. \& Mokhtar, M. (2012). Construction waste minimisation comparing conventional and precast construction (mixed system and IBS) methods in high-rise buildings: a Malaysia case study. Resources, Conservation and Recycling, 63 (2012), 96-103.

23. Technologiya Methallov. (2008). Processing of Metal Radioactive Waste. Retrieved 10/08/2015, from http://www.technologiyametallov.com/engli sch/oekologie_5.htm

24. Suez Environment. (2015). Tree Trunk and Roots. Retrieved 10/08/2015, from http://www.sita.com. au/community-education/site-tours-education/recy cling-tips/tree-trunks-and-root

25. Hair, J.F., Black, W.C., Babin, B.J., \& Anderson, R.E. (2010). Multivariate Data Analysis. Seventh Edition. Prentice Hall, Upper Saddle River, New 
Jersey.

26. Kometa, S.T., Olomolaiye, P.O., \& Harris, F.C. Construction Management \& Economics, 12(5), 433.

27. Mahayuddin, S.A. (2011) Penjanaan, Komposisi dan Pengurusan Sisa binaan: Kajian Kes Ipoh,
(1994). Attributes of UK construction clients influencing project consultants' performance. Perak. Ph.D thesis, Universiti Kebangsaan Malaysia 